\title{
New species of genera Thinobius Kiesenwetter, 1844, of Thinobius pusillimus species group from the West of the European part of Russia
}

\author{
Новый вид рода Thinobius Kiesenwetter, 1844, из группы видов \\ Thinobius pusillimus с запада европейской части России
}

\author{
O.I. Semionenkov \\ О.И. Семионенгов
}

\begin{abstract}
National Park "Smolensk Lakeland", Gurievicha str. 19, Smolensk Area, Przhevalskoye 216270, Russia. E-mail: osemionenkov@yandex.ru Национальный парк “Смоленское Поозерье”, ул. Гуревича 19, Смоленская область, Пржевальское 216270, Россия
\end{abstract}

KEY WORDS: Coleoptera, Staphylinidae, Thinobius, T. pusillimus species group, new species, Smolensk Area. КЛЮЧЕВЫЕ СЛОВА: Coleoptera, Staphylinidae, Thinobius, группа видов T. pusillimus, новый вид, Смоленская область.

ABSTRACT: A new species from genera Thinobius from Smolensk Area is described: T. semenovi sp.n. It is a ninth species from $T$. pusillimus species group a characteristic feature of which is the presence of flagellum in the structure of the aedeagus.

РЕЗЮМЕ: Описывается новый вид рода Thinobius из Смоленской области: T. semenovi sp.n. Это девятый вид из группы видов T. pusillimus, характерным признаком которой служит наличие жгута (флагеллума) в строении эдеагуса.

\section{Introduction}

While studying the Staphylinidae fauna of Smolensk Area, in 2010, a Thinobius Kiesenwetter, 1844 species, firstly determined as $T$. flagellatus Lohse, 1984 was found by us [Gildenkov et al., 2011; Semionenkov et al., 2015]. In 2008 Michael Schülke published a revision of genera Thinobius from T. pusillimus species group, with detailed images of genitalia and redescriptions of some European species [Schülke, 2008]. Further examination of the genital preparations and males terminal abdominal segments of the above mentioned Thinobius from Smolensk Area revealed its essential difference from all known species Thinobius of this species group [Schülke, 2008]. Thus, the species collected by us, is new for a science.

\section{Material and methods}

For the first time the species has been collected in June of 2010 by soil traps on a loamy part of the Dubrovenka River (tributary of the Dnieper River) within the Smolensk city precincts. Later it was found on a sandy bank of the Dnieper River, where it was collected mainly by sifting on well moistened parts, not far than two meters from the water's edge. The greatest part of the type series including the holotype has been collected in the autumn of 2016.

Specimens are pasted on cardboard cards. Genital preparations are made in Canadian balsam for all type series and pinned with the specimens. For some specimens the preparations of the VIII and IX abdominal sternites are made. Photos are taken on Canon 5D Mark III with the lens Canon MP-E $65 \mathrm{~mm}$; the extended focus technology is used. Description and measurements were made with MBS-10 stereoscopic microscope.

We have accepted the following reductions for measurements: AW - maximum width of abdomen; AL approximate length of antenna; BL - approximate body length; EL — length of eye; FL $(\mathrm{h}+\mathrm{p}+\mathrm{e})$ combined length of head, pronotum and elytra; HL head length from the front margin of clypeus to the beginning of neck; HW - head width with eyes; PL length of pronotum in the middle-line; $\mathrm{PW}$ - maximum width of pronotum; SC - length of elytra from the hind apex of scutellum; SL - length of elytra from shoulder; SW - approximate width of shoulders; TL — length of temple; TW - head width at temples. All measurements are from dorsal view.

The places where the material is deposited are indicated by the following means:

ZMUM - Zoological Museum, State University of Moscow, Russia;

MHNG — Natural History Museum, Geneva, Switzerland (Museum d'Histoire Naturelle Geneva);

cMG — private collection of Mikhail Gildenkov, Smolensk, Russia;

cMSch — private collection of Michael Schülke, Berlin, Germany;

cOS - author's private collection, Smolensk, Russia; $\mathrm{cVS}$ - private collection of Viktor Semenov, Moscow, Russia. 


\section{Description}

Thinobius semenovi Semionenkov, sp.n.

TYPE MATERIAL: Holotype ( $\left.O^{7}\right)$ : "Russia, Smolensk Region, Smolensk, Krasny Bor, the sandy bank of the Dnieper River, 24.IX.2016, [leg.] O. Semionenkov / HOLOTYPUS Thinobius semenovi spec. nov., des. O. Semionenkov 2017,, (ZMUM). Paratypes

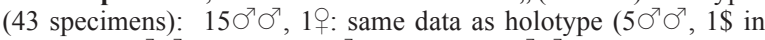
ZMUM, $90^{7} O^{7}$ in cOS, $10^{7}$ in cVS); $30^{7} O^{7}$ : same locality, 26.VIII.2010, [leg.] O. Semionenkov (1 $\sigma^{7}$ in $\operatorname{cOS} 2 \sigma^{7} \sigma^{7}$ in cMG); $100^{7} \sigma^{7}$ : same locality, 29.IX.2016, [leg.] O. Semionenkov $\left(3 \sigma^{7} \sigma^{7}\right.$ in cMSch $7 \sigma^{7} \sigma^{7}$ in cOS); $5 \sigma^{7} \sigma^{7}$, 2o+o: same locality, 9.X.2016, [leg.] O. Semionenkov $\left(30^{7} O^{7}\right.$ in MNHG $20^{7} O^{7}$, 2 우 in $\operatorname{cOS}$ ); $60^{7} \mathrm{O}^{7}, 1$, "Smolensk Region, Smolensk, Krasny Bor, spillway of Dubrovenskoye Lake, 29.VI.2010, [leg.] O. Semionenkov" (10 in ZMUM, $50^{7} \mathrm{O}^{7}, 1$ 우 in $\mathrm{cOS}$ )

DESCRIPTION. Measurements of holotype (in $\mathrm{mm}$ ): AW: 0.238; AL: 0.35; BL: 1.064 (without terminal abdominal segments); EL: 0.07; FL: 0.658; HL: 0.168; HW: 0.203; PL: 0.168; PW: 0.238; SC: 0.252; SL: 0.294; SW: 0.280; TL; 0.028; TW: 0.196. Completely black. Elytra black, less often slightly lighter, than the head, pronotum and abdomen (depending on the maturity of specimen). Legs, mouthparts and antennae are from brown to dark-brown. Apexes of tibiae and tarsi are light-brown. Body length from 1.05 to $1.50 \mathrm{~mm}$. Forebody is covered with a short light pubescence. On the anterior edge of clypeus and posterior edges of tergites pubescence is slightly longer. On the outside of tibiae and side edges of pronotum (closer to the anterior angles) there are a few much longer and dark setae.

Head (Fig. 1) is several transverse, maximum width in eyes (approximate relation of length to width $-0.8: 1$ ). The surface of head is uniformly convex, with no visible impressions. Eyes are somewhat in favor of the contour of the head, temples are slightly expanded. The surface of the head is covered with a dense and fine punctures. Antennae (Fig. 1) are rather short. The first two antennomeres are elongated, cone-shaped (approximate relation of length to width of first - 2:1, of second $-1.4: 1)$. The third and fifth antennomeres are much shorter than the first two, somewhat cone-shaped, slightly elongated (approximate relation of length to width 1.2:1). The fourth and sixth antennomeres are of the smallest size, shortened-cylindrical form, and their length is approximately equal to the width. The seventh and eighth are a little cone-shaped, larger than previous; their length is approximately equal to the width. The ninth and tenth antennomeres are slightly cone-shaped, much larger than 7 and 8; their length is also approximately equal to the width. The eleventh antennomere is elongate and pointed to the top (approximate relation of length to width $-1,4: 1$ ).

Pronotum (Fig. 1) is clearly transversal. Approximate relation of length to width $-0.6: 1$. Smoothly extends from the rounded posterior angle and reaches the greatest width, without reaching about $1 / 4$ to the anterior angle, forming poorly expressed obtuse angle, then it is gradually narrowed. The anterior angles are obtuse. The surface of disc is covered with dense and fine punctation. The character of punctation is similar to the punctation of head. On the basis of pronotum on both sides from the medial line there are two poorly expressed spherical impressions.

Scutellum is of a triangular shape, covered by fine and dense punctation. Elytra (Fig. 1) are parallel-sided, weakly dilating posteriorly and almost twice more longer than pronotum (PL:SL - approximately 0.6:1). Length and width of elytra are approximately equal (approximate relation of length to width: 1.05:1). Humeral angles are well expressed, round-
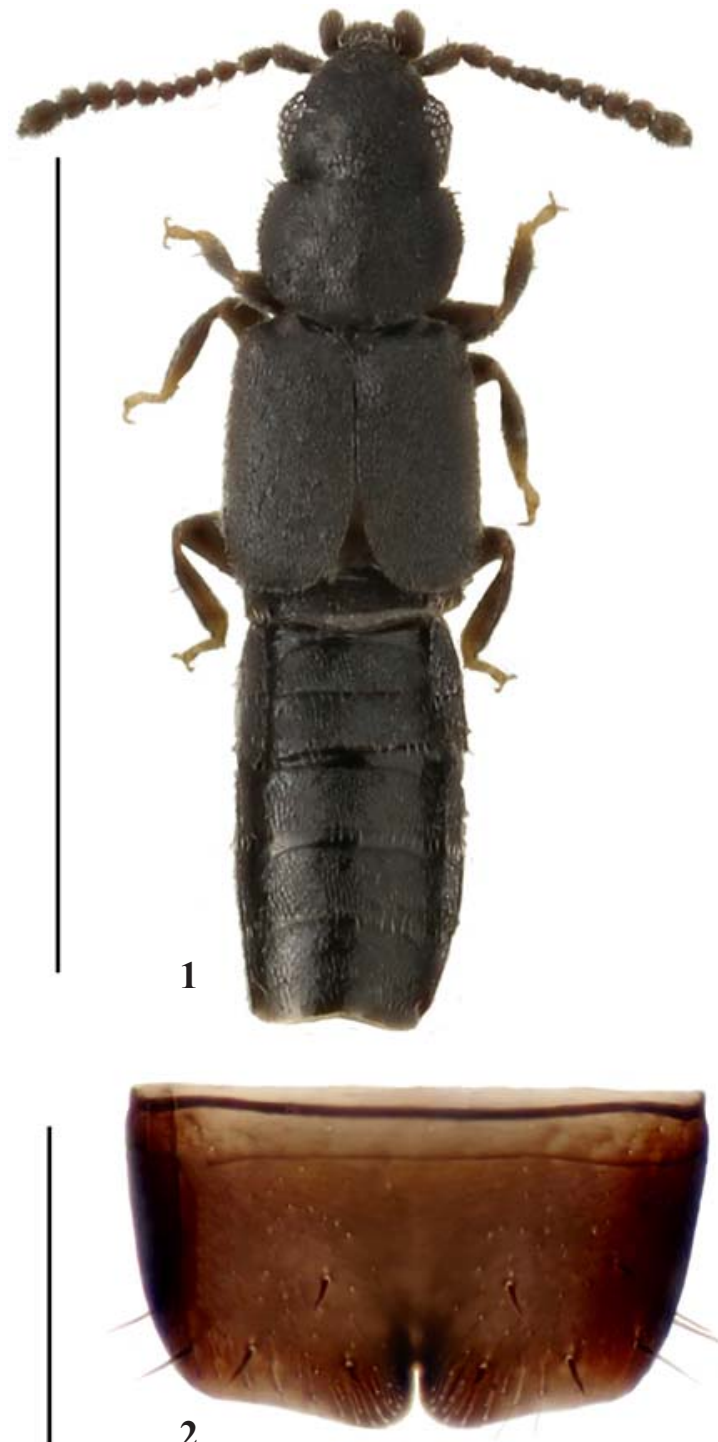

2

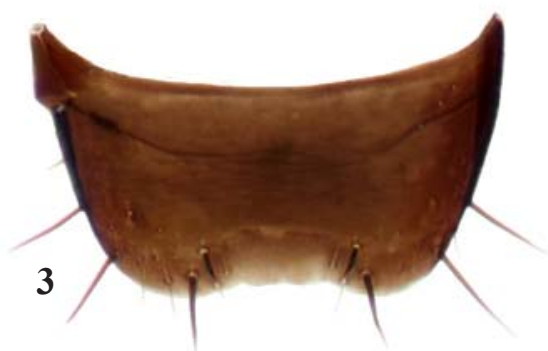

Figs. 1-3. Thinobius semenovi Semionenkov, sp.n. $0^{7}$ paratype: 1 - habitus, dorsal view; 2-3 - sternites VIII and IX. Scale bars: $1.0 \mathrm{~mm}(1), 0.2(2-3) \mathrm{mm}$.

Рис. 1-3. Thinobius semenovi Semionenkov, sp.n. $0^{7}$ паратип: 1 - общий вид, сверху; 2, 3 - стерниты VIII и IX. Масштаб: 1,0 мм (1), 0,2 (2-3) мм. 
ed. Posterior angles are rounded. Elytra are widely rounded in suture angles, and the suture is closed throughout only about $1 / 2$ of their length, considering from hind apex of scutellum. Elytra are some more densely and gently punctated than the head and pronotum.

Abdomen is weakly fusiform (Fig. 1). Tergites are covered by fine and dense punctation with a distinctive microsculpture.

Males and females practically do not differ externally. VIII and IX male sternites have cutouts on posterior edge and characteristically located setae (Figs 2-3). Aedeagus and spermatheca have a characteristic structure (Figs 4-8).

DIFFERENTIAL DIAGNOSIS. A new species well differs from all other species of the group [Schülke, 2008] by the structure of the aedeagus and male terminal abdominal segments (Figs 2-7). Spermatheca is rather distinctive (Fig. 8), well differs from spermatheca of the related species $T$. flagellatus [Makranczi, 2009].
ECOLOGY AND DISTRIBUTION. The species has been collected in the riverside and temporary flood waters zone on the loamy and sandy banks of the Dnieper River basin (Fig. 9). For the present time the species is known only from the Smolensk Area. Perhaps, some records of T. flagellatus and T. pusillimus (Heer, 1839) from Europe (especially its Eastern part) can belong to $T$. semenovi sp.n.

ETYMOLOGY: The species is named after Viktor Borisovich Semenov - Russian entomologist, specialist in fauna and taxonomy of Staphylinidae (subfamily Aleocharinae).

ACKNOWLEDGEMENTS. The author is sincerely thankful to Michael Schülke (Berlin, Germany) for a detailed consultation on a Thinobius found in Smolensk Area, and also to Mikhail Gildenkov (Smolensk, Russia) for his valuable advice while writing the article. Special thanks to Kirill Makarov (Moscow, Russia) for taken the photos.

$$
\text { . }
$$

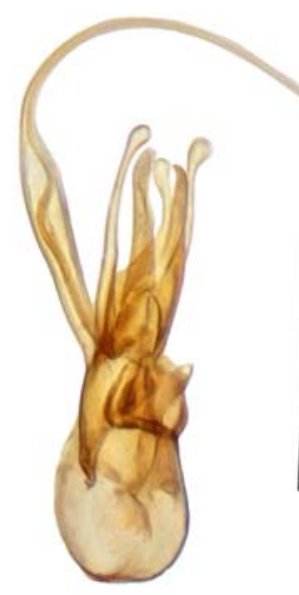

4

4

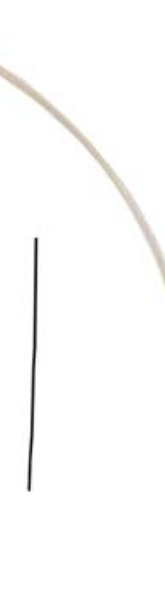

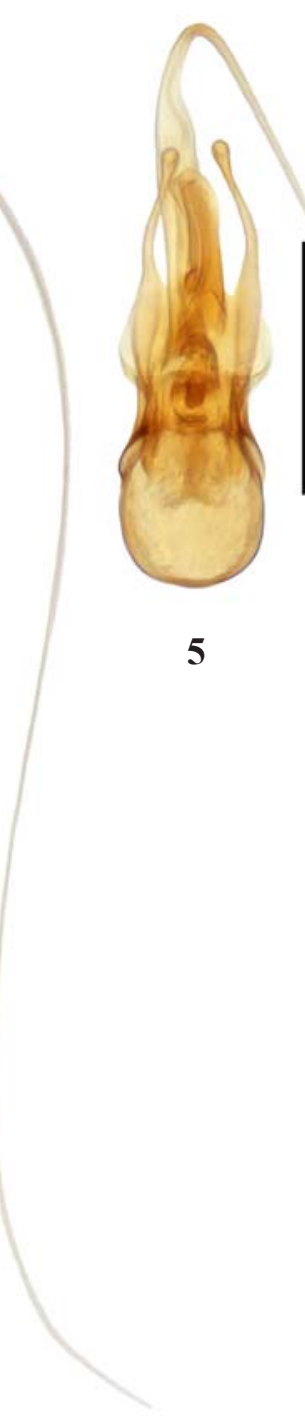

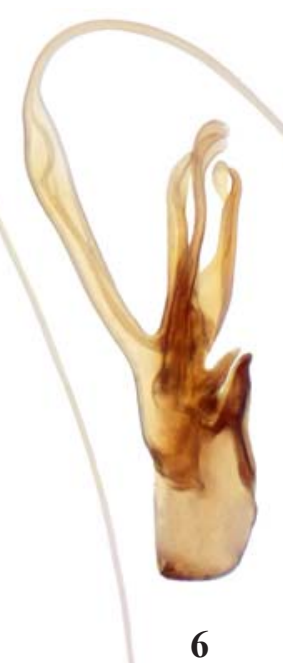

8

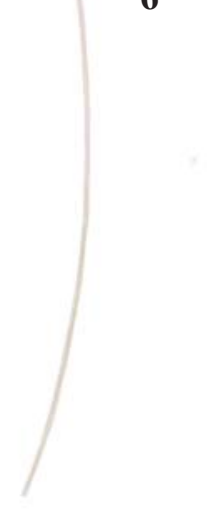

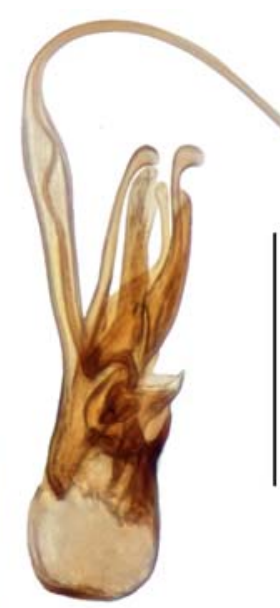

7

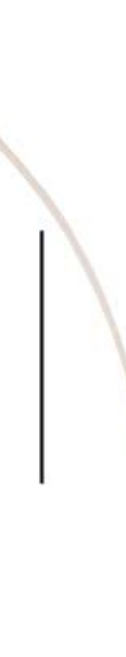

8 


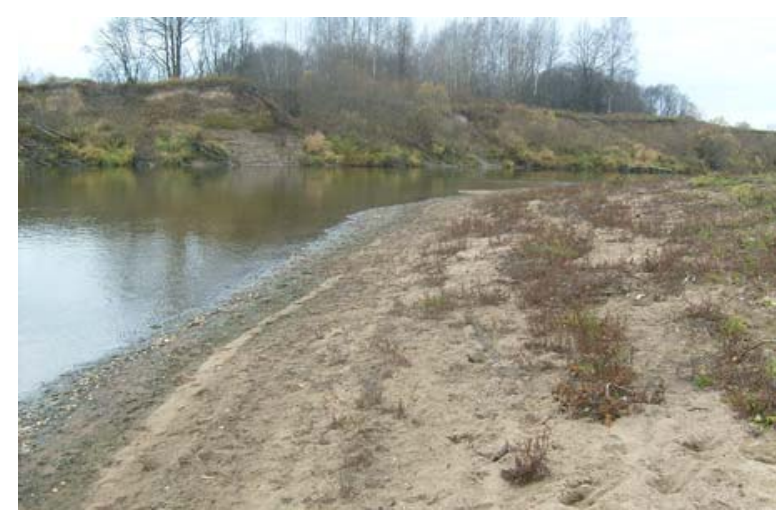

Fig. 9. Type locality of Thinobius semenovi sp.n.: Smolensk, Krasny Bor, the sandy bank of the Dnieper River.

Рис. 9. Типовое местонахождение Thinobius semenovi sp.n.: Смоленск, Красный Бор, песчаный берег р. Днепр.

\section{References}

Gildenkov M.Yu., Semionenkov O.I., Starodubtseva O.A. 2011. [Rove beetles of the subfamily Oxytelynae (Coleoptera, Staphylinidae) of Smolensk Region] // Izvestiya Smolenskogo gosudarstvennogo universiteta. Smolensk. No.3(15). P.261279 [in Russian, with English summary].

Makranczi G. 2009. Two interesting Thinobius species collected at the River Vi eu in Maramure (Romania) (Coleoptera: Staphylinidae: Oxytelinae) // Travaux du Muséum National d'Histoire Naturelle "Grigore Antipa". Vol.52. P.249-261.

Schülke M. 2008. Revision der pusillimus-Gruppe der Gattung Thinobius Kiesenwetter mit Beschreibung von fünf neuen Arten (Staphylinidae, Oxytelini, Thinobiini) // Entomologische Blatter. Bd.103/104. S.11-42.

Semionenkov O.I., Semenov V.B., Gildenkov M.Yu. 2015. Rove beetles (Coleoptera, Staphylinidae) of the West of the European part of Russia (excepting subfamilies Pselaphinae, Scydmaeninae and Scaphidiinae). Smolensk: Universum. 388 pp. 